\title{
Reduced IFN- $\gamma$ and IL-10 responses to paternal antigens during and after pregnancy in allergic women
}

Marie Persson, Christina Ekerfelt, Jan Ernerudh, Leif Matthiesen, Martina Sandberg, Yvonne Jonsson, Göran Berg and Maria C. Jenmalm

\section{Linköping University Post Print}

\section{Tweet}

N.B.: When citing this work, cite the original article.

Original Publication:

Marie Persson, Christina Ekerfelt, Jan Ernerudh, Leif Matthiesen, Martina Sandberg, Yvonne Jonsson, Göran Berg and Maria C. Jenmalm, Reduced IFN- $\gamma$ and IL-10 responses to paternal antigens during and after pregnancy in allergic women, 2012, Journal of Reproductive Immunology, (95), 1-2, 50-58.

http://dx.doi.org/10.1016/j.jri.2012.05.003

Copyright: Elsevier http://www.elsevier.com/

Postprint available at: Linköping University Electronic Press

http://urn.kb.se/resolve?urn=urn:nbn:se:liu:diva-84900 


\section{REDUCED IFN- $\gamma$ AND IL-10 RESPONSES TO PATERNAL ANTIGENS \\ DURING AND AFTER PREGNANCY IN ALLERGIC WOMEN}

Marie Persson, B.Sc ${ }^{\mathrm{a}}$

Christina Ekerfelt, Ph.D ${ }^{\mathrm{a}}$

Jan Ernerudh, M.D, Ph.D

Leif Matthiesen, M.D., Ph.D. ${ }^{\mathrm{c}}$

Martina Sandberg Abelius, M.Sc.,

Yvonne Jonsson, Ph.D ${ }^{\mathrm{a}}$

Göran Berg, M.D, Ph.D

Maria C Jenmalm, Ph.D ${ }^{\mathrm{a}}$

${ }^{a}$ Clinical Immunology, Department of Clinical and Experimental Medicine, Faculty of Health Sciences, Linköping University, Sweden

${ }^{\mathrm{b}}$ Obstetrics and Gynecology, Department of Clinical and Experimental Medicine, Faculty of Health Sciences, Linköping University, Sweden

${ }^{c}$ Department of Obstetrics and Gynecology, Helsingborg Hospital, Helsingborg, Sweden

${ }^{\mathrm{d}}$ Division of Pediatrics, Department of Clinical and Experimental Medicine and Clinical Research

Centre, Faculty of Health Sciences, Linköping University, Sweden

Corresponding author:

Marie Persson, B.Sc.

$\square$ AIR, Pathology Building, Floor 10, Division of Inflammation Medicine, Department of Clinical and Experimental Medicine, Faculty of Health Sciences, University of Linköping, SE-581 85

Linköping, Sweden

๑marie.h.persson@liu.se 


\begin{abstract}
Normal pregnancy and allergy are both characterized by a T helper (Th) 2 deviation. In the current study, we hypothesized that paternal antigen-induced cytokine responses during pregnancy would be deviated towards $\mathrm{Th} 2$ and an anti-inflammatory profile, and that the Th2 deviation would be more pronounced in allergic pregnant women. Blood samples were collected longitudinally on three occasions during pregnancy and two occasions post partum $(p p)$. Of the 86 women initially included, 54 women had a normal pregnancy and completed the sampling procedures. Twelve women fulfilled the criteria for allergy (allergic symptoms and circulating immunoglobulin (Ig) E antibodies to inhalant allergens) and 20 were nonallergic (nonsensitized without symptoms). The levels of Th1 and Th2 associated cytokines and chemokines, the Th17 cytokine IL-17 and the anti-inflammatory cytokine IL-10 were compared between the groups. Paternal antigen induced IL-4 and IL-10 responses increased from the first to the third trimester. Allergy was associated with a decreased paternal antigeninduced IFN- $\gamma$ and CXCL10 secretion in the non-pregnant state (one year post partum) and also decreased IFN- $\gamma / \mathrm{IL}-4$ and IFN- $\gamma / \mathrm{IL}-13$ ratios during pregnancy. We also observed a decreased paternal antigen induced IL-10 response in allergic compared with non-allergic women during pregnancy, along with a decreased IL-10/IL-13 ratio. In conclusion, our findings support the hypothesis of lower Th1 responses towards paternal antigens in allergic than in non-allergic women but also indicate that allergy is associated with a lower capacity to induce anti-inflammatory IL-10 responses after paternal antigen stimulation during pregnancy.
\end{abstract}

Key words: Allergy, Th1/Th2, pregnancy 


\section{Abbreviations}

Immunoglobulin $\quad$ Ig

Mixed leukocyte culture $\quad$ MLC

Mixed leukocyte reaction MLR

Post partum $\quad p p$

$\begin{array}{ll}\text { Regulatory } \mathrm{T} \text { cells } & \text { Treg cells }\end{array}$

$\begin{array}{ll}\text { T helper } & \text { Th }\end{array}$ 


\section{Introduction}

A redirection of Th1/Th2 immune responses towards Th2-type immune responses has been suggested during normal pregnancy (Wegmann et al. 1993; Ekerfelt et al. 1997; Raghupathy et al. 2000; Persson et al. 2008). Previously, we have observed higher numbers of both IFN- $\gamma$ and IL-4-secreting peripheral blood mononuclear cells (PBMC) in pregnant than in nonpregnant women (Matthiesen et al. 1998) and increased numbers of IL-4-secreting PBMC in pregnant women in response to paternal allo-antigens, indicating a Th2-response directed against the fetus during pregnancy (Ekerfelt et al. 1997).

Increased IFN- $\gamma$ levels have been found in women with unexplained recurrent spontaneous abortions after stimulation of maternal PBMC with irradiated autologous placental cells (Raghupathy et al. 1999). Furthermore, women with pregnancy losses show increased Th1-like and decreased Th2-like responses after stimulation of maternal PBMC with strong unspecific stimuli, whereas women with successful pregnancies seem to have increased Th2-like responses (Raghupathy et al. 2000; Makhseed et al. 2001; Kwak-Kim et al. 2003; Guo et al. 2010). Also, high levels of the anti-inflammatory cytokine IL-10 have been associated with improved pregnancy outcomes, both spontaneously and after stimulation with trophoblast cell line extracts (Wu et al. 2001; Ginsburg et al. 2005), whereas low serum IL-10 levels and high serum levels of the proinflammatory cytokines IL-6, TNF and IFN- $\gamma$ were associated with symptoms of threatened spontaneous abortion (Hudic and Fatusic 2009).

The Th1/Th2 paradigm has now been expanded into the Th1/Th2/Th17 and regulatory $\mathrm{T}$ (Treg) cell paradigm. Th17 cells secrete the pro-inflammatory cytokine IL-17 and thus play an important role in the induction of inflammation (Milner 2011). Treg cells induce tolerance by several mechanisms (Peterson 2012) including IL-10 secretion. Decreased numbers of Treg cells and increased numbers of Th17 cells have been observed after stimulation with decidual lymphocytes or PMA/ionomycin in women with unexplained recurrent miscarriage 
(Wang et al. 2010b; Ernerudh et al. 2011). Following stimulation with PMA/ionomycin, higher IL-17 expression levels and a decreased suppressive ability by Tregs on IL-17 secretion in women with unexplained early recurrent miscarriage have also been found (Wang et al. 2010a). In summary, the results of previous studies suggest that a Th2 deviation and an anti-inflammatory profile are beneficial for pregnancy while Th1 and Th17 responses may be detrimental.

Strong mitogenic stimuli such as PMA/ionomycin (Kwak-Kim et al. 2003; Wang et al. 2010a), PHA (Raghupathy et al. 2000; Makhseed et al. 2001) as well as trophoblast cell line extracts (Raghupathy et al. 1999; Ginsburg et al. 2005) have previously been used as stimuli, whereas we here wanted to investigate paternal antigen-induced responses during pregnancy.

Similar to normal pregnancy, allergy is characterized by a Th2 deviation. Allergic individuals have a predisposition to produce high $\operatorname{IgE}$ antibody levels and Th2 cytokines, such as IL-4, IL-5 and IL-13, in response to environmental allergens (Parronchi et al. 1992; Jenmalm et al. 2001; Machura et al. 2010). Furthermore, allergic patients have an enhanced ability to produce IL-4 not only in response to allergens, but also to other antigens (Parronchi et al. 1992). Allergic disease is associated with a generally lowered IFN- $\gamma$ secretion following stimulation with vaccine antigens and allergens (Parronchi et al. 1991; Shimojo et al. 1996).

The Th2 deviation in allergic disease may be beneficial for a successful pregnancy outcome. In support of this hypothesis, mothers with allergic disease (i.e. hay fever, allergic rhinitis, asthma or dermatitis) were found to have more children than non-allergic mothers (Nilsson et al. 1997). Furthermore, mothers of premature very low birth weight infants had less allergic rhinitis than mothers of full-term normal weight infants (Savilahti et al. 2004) and maternal allergic rhinitis was associated with high birth weight and long gestational age in the offspring (Somoskovi et al. 2007). Also, women with allergic rhinitis had a shorter waiting time to pregnancy as compared with women not reporting allergic rhinitis (Westergaard et al. 
2003) and women with eczema or hay fever had a possibly increased fertility rate (Tata et al. 2007), further supporting the potential benefit of allergy for pregnancy outcome. However, an inverse relationship between maternal allergy and the number of offspring has also been reported (Karmaus and Eneli 2003; Sunyer et al. 2005). Furthermore, several other factors may influence the outcome of pregnancy.

While Th17 status in pregnancy has not previously been investigated in relation to allergy, the Th2 deviation associated with pregnancy has been shown to be intensified in allergic pregnant women, both in general terms measured by total IgE levels (Sandberg et al. 2009b) and in relation to allergen responsiveness (Breckler et al 2010). Furthermore, a lower relative Th1/Th2 production was observed in allergic pregnant women by mixed leukocyte reactions (MLR) using irradiated cord blood cells as a proxy for fetal antigens (Breckler et al. 2008; Prescott et al. 2009). We have previously developed an MLR using inactivated paternal cells as a proxy for allogeneic fetal cells (Ekerfelt et al. 1997).

We hypothesize that paternal antigen-induced cytokine responses during pregnancy are deviated towards Th2 and an anti-inflammatory profile, and that the Th2 deviation is more pronounced in allergic pregnant women. The aim of this study was to test this hypothesis and to explore the possible role of Th17 in Th subset balance in pregnancy by comparing the levels of Th1 (IFN- $\gamma$ ), Th2 (IL-4 and IL-13), Th17 (IL-17) and anti-inflammatory (IL-10) cytokines as well as Th1 (CXCL10) and Th2 (CCL17) associated chemokines secreted by maternal cells in response to paternal antigens in women with or without allergy. In supplement to previous studies, we also investigated immune status one year post partum, thereby representing a non-pregnant situation. 


\section{Materials and methods}

\subsection{Subjects}

The 86 pregnant women included in this study (Fig. 1) were all attending the Antenatal Clinic at the University Hospital in Linköping. All women accepted to participate after informed consent. The study was approved by the Human Research Ethics Committee at the Faculty of Health Sciences in Linköping.

The allergic status was established by a typical clinical history, e.g. allergic rhinoconjunctivitis, allergic asthma or flexural itchy eczema. An experienced allergy research nurse used a structured questionnaire to interview the women. To further strengthen the diagnosis, an allergy screening was performed using the Phadiatop ${ }^{\circledR}$ system (Pharmacia Diagnostics, Uppsala, Sweden), detecting circulating IgE antibodies against common inhalant allergens; birch, mugwort, timothy, cat, dog, horse, house-dust mite and Cladosporium. Women who had both typical symptoms and a positive Phadiatop test were considered true allergic, while women with no symptoms and a negative Phadiatop test were considered true non-allergic. Twenty-seven women later declined to participate in the study, and five women miscarried. Fifty-four women gave birth to a healthy child and completed sampling procedures and 32 of these fulfilled either of the criteria for diagnosis of allergy $(n=12$, age 26.0-37.2 years; median 30.4 years) or absence of allergy ( $n=20$, age 26.2-39.7 years; median 30.0 years) (Fig. 1). Corresponding paternal cells were not collected from 4 mothers and supernatants could not be collected from 4 mothers. Of the remaining 14 women, seven had allergic symptoms but were non-sensitized, six had no symptoms but were sensitized and one mother had allergic symptoms but the Phadiatop test could not be performed.

\subsection{Collection of samples}


Heparinized blood samples were collected on three occasions during pregnancy (gestational weeks 10-12, 25 and 39), and 12 months pp. All blood samples were drawn between 8 a.m. and 2 p.m. and processed within 4 h. Corresponding paternal PBMC were collected on one occasion and blood from 18 unrelated donors was obtained from The Department of Transfusion Medicine at the University Hospital, Linköping.

\subsection{PBMC isolation}

PBMC were isolated from heparinized blood and frozen as previously described (Persson et al. 2008). The same procedure for separation and freezing was used for the paternal and pooled unrelated PBMC as for the PBMC from the pregnant women.

\subsection{Inhibition of stimulator cells}

The stimulator cells, i.e. paternal PBMC or PBMC from unrelated donors, were treated with 4\% paraformaldehyde (PFA; Merck Eurolab AB, Stockholm, Sweden) in phosphate-buffered saline (PBS; EC Diagnostics AB, Uppsala, Sweden) for 10 minutes at room temperature (RT) to inhibit cytokine secretion as previously described (Ekerfelt et al. 1997).

\subsection{Mixed leukocyte culture (MLC)}

One-way MLC was performed in polypropylene tubes. Briefly, 0.8 x $10^{6}$ responder PBMC (maternal cells) in $800 \mu \mathrm{L}$ of complete medium was co-cultured with $0.8 \times 10^{6}$ PFA-treated paternal PBMC or PFA-treated PBMC from unrelated donors in $800 \mu \mathrm{L}$ of complete medium, in replicates of three. The cultures were incubated for 7 days at $37^{\circ} \mathrm{C}$ in a $5 \% \mathrm{CO}_{2}$ atmosphere.

\subsection{Determination of cytokine concentrations}


The cytokines IFN- $\gamma$, IL-4, IL-10 and IL-17 were analyzed by Milliplex ${ }^{\mathrm{TM}}$ MAP kits (Millipore Corporation, Billerica, USA) according to the manufacturer's instructions using the Luminex 100 instrument (Biosource, Nivelles, Belgium). StarStation software (version 2.3; Applied Cytometry Systems, Sheffield, UK) was used for acquisition and analysis of data. The range of the standard curves was 3.2-2000 pg/mL for IFN- $\gamma$, IL-4 and IL-10; 0.64-2000 $\mathrm{pg} / \mathrm{mL}$ for IL-17; with a dilution factor of 5. The chemokines CXCL10 and CCL17 were analysed with a Luminex assay as previously described (Abrahamsson et al. 2011). The range of the standard curves was 5.5-1333 pg/mL for CXCL10; and 1.92-467 pg/mL for CCL17. The levels of IL-13 were determined using enzyme-linked immunosorbent assay (ELISA) as previously described (Böttcher et al. 2003) and the range of the standard curve was 2.0-64.0 $\mathrm{pg} / \mathrm{mL}$. All detection limits were equal to the lowest standard and values below the detection limit were given half the value of the detection limit.

\subsection{Statistics}

Data was analyzed with SPSS, version 19 (SPSS Inc., Chicago, IL, USA). Mann-Whitney Utest was used for the comparison of cytokine levels between allergic and non-allergic pregnant women. Friedman's test was used to investigate changes in cytokine levels during pregnancy, regardless of allergic status. Differences in cytokine levels between time points were examined with Wilcoxon's signed rank test. The criterion for statistical significance was $p<0.05$. Calculations of cytokine ratios were made by dividing the value of for example paternal-stimulated IFN-g (Th1) with the value of paternal-stimulated IL-4 (Th2). 


\section{Results}

Allergic women showed, compared with non-allergic women, lower paternal antigen-induced Th1 responses one year $p p$ as measured by IFN- $\gamma$ (Fig. 2a) and CXCL10 secretion (Table 1). In response to pooled unrelated antigen, allergic women showed a lower IFN- $\gamma$ response than non-allergic women in the second trimester (Fig. 2b). Lower responses in allergic women were also recorded for the immunosuppressive cytokine IL-10; significantly lower secretion as compared with non-pregnant women was observed for paternal antigen-induced secretion in the second trimester (Fig. 2c) and for pooled unrelated antigen-induced secretion in the first and second trimesters (Fig. 2d). The non-allergic women showed a higher pooled unrelated antigen-induced secretion of IL-13 one year $p p$ than the allergic women (Table 1). The paternal or pooled unrelated antigen-induced secretion of IL-4, IL-17 and CCL17 were similar in allergic and non-allergic women.

The ratio of paternal antigen-induced IFN- $\gamma / \mathrm{IL}-4$ production was lower in the third trimester and one year $p p$ in allergic than in non-allergic women (Fig. 3a), as well as the paternal antigen-induced IFN- $\gamma / \mathrm{IL}-13$ ratio in the third trimester (Fig 3b). Allergy was also associated with a lower pooled unrelated antigen-induced IL-10/IL-4 ratio in the first trimester (median=2.2 for allergic women; 10.2 for non-allergic women (range=1.0-16.8 and 1.0-312.2, respectively)), with similar tendencies for the paternal antigen-induced IL-10/IL-4 ratio (Fig 3c). Furthermore, lower IL-10/IL-13 - regarding both paternal antigen- (Fig 3d) and pooled unrelated antigen- (median=2.0 for allergic women; 22.7 for non-allergic women $($ range $=1.3-362.5$ and 1.6-107.6, respectively) $)$ induced secretion - were observed among the allergic than non-allergic women in the third trimester.

Paired comparisons during the course of pregnancy and $p p$ in the non-allergic women showed significantly higher pooled unrelated antigen-induced IFN- $\gamma$, IL-17 and CCL17 levels in the second than the third trimester (Fig 4a, b, c respectively). Furthermore, pooled 
unrelated antigen-induced CXCL10 secretion was higher in the third than the first trimester (Fig 4d).

\section{Discussion}

Allergy was associated with decreased paternal antigen-induced IFN- $\gamma /$ IL-4 and IFN- $\gamma /$ IL-13 ratios in the third trimester, which is in line with previous findings of other investigators and supporting the hypothesis of augmented paternal-specific Th2 responses in allergic women during pregnancy. Our findings indicate that this Th2 deviation holds true also for unrelated non-paternal antigens. Interestingly, allergy was associated with a decreased paternal antigeninduced IFN- $\gamma$ and CXCL10 secretion as well as a decreased IFN- $\gamma /$ IL-4 ratio also in the nonpregnant state. This indicates that Th2-biased responses remain after pregnancy, indeed being a pre-requisite for reported beneficial effects of allergy for fertility (Westergaard et al. 2003; Tata et al. 2007). Although the study design did not provide any possibility to analyze the responses before pregnancy, it would be tempting to speculate that these differences also are present before pregnancy.

A lower IFN- $\gamma$ response to cord blood mononuclear cells has been found in allergic compared with non-allergic pregnant women in the third trimester (Breckler et al. 2008). Further, allergic women have showed significantly lower IFN- $\gamma$ and relative Th1/Th2 responses to fetal HLA-DR $\beta 1$ mismatch during pregnancy (Prescott et al. 2009). In a previous study, we found similar responses toward paternal and unrelated pooled antigens in allergic and non-allergic women in the same cohort as in the present study (Persson et al. 2008). However, the numbers of cytokine secreting cells were measured by ELISpot, while ELISA and multiplex bead array systems were used in the present study to measure cytokine concentrations in cell supernatants. We have shown that individual results from different assays do not correlate, suggesting that the amount of cytokine secreted is not proportional to 
the number of cytokine secreting cells (Ekerfelt et al. 2002). Furthermore, we have previously found a higher increase in total IgE levels in allergic than non-allergic mothers in early pregnancy in the same cohort as in the present study, lending further support to a more enhanced Th2 deviation in allergic women during pregnancy (Sandberg et al. 2009b).

Considering the possibly protective role of IL-10 in pregnancy (Wu et al. 2001; Ginsburg et al. 2005) and the association of low serum IL-10 levels and spontaneous abortion (Hudic and Fatusic 2009), one might expect an increased production of IL-10 during pregnancy. However, we observed a lower paternal antigen-induced IL-10 response in the second trimester in allergic than non-allergic women along with a decreased IL-10/IL-13 ratio in the third trimester. Several other studies have also found a decreased IL-10 production in allergic compared with non-allergic individuals (Jenmalm et al. 2001; Dunstan et al. 2005;

Seneviratne et al. 2006). Altogether, these results may argue for a regulating role of IL-10 in the pathogenesis of allergic disease.

Among the non-allergic women, the pooled antigen-induced cytokine secretion changed during the course of pregnancy. The levels of IFN- $\gamma$, CCL17 and IL-17 were higher in the second than in the third trimester while the CXCL10 levels increased from the first to the second trimester. Recently, Breckler et al. observed suppressed fetal antigen-induced cytokine (IFN- $\gamma$, IL-6, IL-10, IL-13) responses in the third trimester compared with six weeks $p p$ (Breckler et al. 2008). In contrast, we have previously shown that the major changes in spontaneous and paternal antigen-induced cytokine secretion occur in the second and third trimesters at the systemic level (Persson et al. 2008). However, in the study by Breckler et al., cytokine responses were compared between the third trimester and 6 weeks $p p$, whereas all three trimesters and 12 months $p p$ were compared in our previous study, possibly explaining the discrepancy. 
The unrelated pooled antigen-induced secretion of IL-17 was higher in the second than in the third trimester. We have recently reported that Th17 cells are scarce in decidua compared with peripheral blood (Mjösberg et al. 2010), while, conversely, it was also reported that the proportion of $\mathrm{IL}-17^{+} \mathrm{CD} 4^{+}$cells was higher in the decidua compared with peripheral blood in the first trimester (Nakashima et al. 2010). In the study of Nakashima et al., PMA-ionomycin stimulated cells were investigated, whereas our previous study was performed on unstimulated cells. Notably, in the present study we found no evidence of an association between circulating IL-17 levels and allergic status. However, the role of Th17 immunity in allergic disease is not clear (reviewed in (Milner 2011)).

The observed more pronounced Th2 deviation in allergic women during pregnancy may have an impact on neonatal Th1/Th2 responses. In line with this, several studies suggest that a maternal history of allergic disease constitutes a greater risk than paternal for development of infant allergic disease (Lim et al. 2010). Maternal, but not paternal, total IgE levels have been found to correlate with cord blood IgE levels and allergy in the infant (Liu et al. 2003), and Sadegnejad et al. observed a stronger association between increased cord blood IgE levels and allergic disease in the mother than in the father (Sadeghnejad et al. 2004). Elevated cord blood IgE has been identified as a risk factor for allergic sensitization and asthma (Sadeghnejad et al. 2004). The observed Th2 deviation during pregnancy not only remains one year after pregnancy but may also influence further development of allergy in the offspring. In a recent study, we found positive correlations between the levels of maternal IgE and cord blood levels of IgE and the Th2-associated chemokine CCL22 (Sandberg et al. 2009a). Furthermore, increased cord blood CCL22 levels, as well as increased cord blood IgE levels, at birth was associated with development of allergic disease in the child during the first two years of life. Moreover, elevated cord blood CCL17 levels can predict development of recurrent wheeze 
and asthma and cord blood CCL22 development of sensitization later in life (Abelius et al. 2011; Abrahamsson et al. 2011).

One limitation of the paper is the size of the study populations. However, we wanted to evaluate only strictly defined allergic and non-allergic women. Furthermore, as several data were in the same direction as changes that were statistically significant, it is likely that a larger material would have further strengthened the hypothesis.

In conclusion, our findings support the hypothesis of lower Th1 responses towards paternal antigens in allergic than in non-allergic pregnant women but also indicate that allergy is associated with a lower capacity to induce anti-inflammatory IL-10 responses after paternal antigen stimulation during pregnancy. 


\section{Acknowledgements}

We would like to thank participating couples and staff at the maternity health care clinic. Anne-Marie Fornander, Linda Widar, Eva Hellqvist and research nurse Lena Lindell are acknowledged for excellent technical and clinical assistance. This work was supported by the Swedish Research Council, the Cancer and Allergy Association, the Olle Engkvist Foundation, the Vårdal Foundation — for Health Care Sciences and Allergy Research, the National Swedish Association against Allergic Diseases and Linköping University Hospital. 


\section{References}

Abelius, M. S., Ernerudh, J., Berg, G., Matthiesen, L., Nilsson, L. J.,Jenmalm, M. C., 2011. High cord blood levels of the T-helper 2-associated chemokines CCL17 and CCL22 precede allergy development during the first 6 years of life. Pediatr Res. 70, 495-500

Abrahamsson, T. R., Sandberg Abelius, M., Forsberg, A., Bjorksten, B.,Jenmalm, M. C., 2011. A Th1/Th2-associated chemokine imbalance during infancy in children developing eczema, wheeze and sensitization. Clin Exp Allergy. 41, 1729-1739

Breckler, L. A., Hale, J., Taylor, A., Dunstan, J. A., Thornton, C. A.,Prescott, S. L., 2008. Pregnancy IFNgamma responses to foetal alloantigens are altered by maternal allergy and gravidity status. Allergy. 63, 1473-1480

Böttcher, M. F., Bjurstrom, J., Mai, X. M., Nilsson, L.,Jenmalm, M. C., 2003. Allergen-induced cytokine secretion in atopic and non-atopic asthmatic children. Pediatr Allergy Immunol. 14, 345-350

Dunstan, J. A., Hale, J., Breckler, L., Lehmann, H., Weston, S., Richmond, P.,Prescott, S. L., 2005. Atopic dermatitis in young children is associated with impaired interleukin-10 and interferongamma responses to allergens, vaccines and colonizing skin and gut bacteria. Clin Exp Allergy. 35, 1309-1317

Ekerfelt, C., Ernerudh, J.Jenmalm, M. C., 2002. Detection of spontaneous and antigen-induced human interleukin-4 responses in vitro: comparison of ELISPOT, a novel ELISA and real-time RT-PCR. J Immunol Methods. 260, 55-67

Ekerfelt, C., Matthiesen, L., Berg, G.,Ernerudh, J., 1997. Paternal leukocytes selectively increase secretion of IL-4 in peripheral blood during normal pregnancies: demonstrated by a novel one-way MLC measuring cytokine secretion. Am J Reprod Immunol. 38, 320-326

Ernerudh, J., Berg, G.,Mjosberg, J., 2011. Regulatory T helper cells in pregnancy and their roles in systemic versus local immune tolerance. Am J Reprod Immunol. 66 Suppl 1, 31-43

Ginsburg, E. S., Xiao, L., Gargiulo, A. R., Kung, F. T., Politch, J. A., Schust, D. J.,Hill, J. A., 2005. T-helper 2 and 3 type immunity to trophoblast in successful in vitro fertilization-embryo transfer. Fertil Steril. 83, 1659-1664

Guo, P. F., Du, M. R., Wu, H. X., Lin, Y., Jin, L. P.,Li, D. J., 2010. Thymic stromal lymphopoietin from trophoblasts induces dendritic cell-mediated regulatory $\mathrm{TH} 2$ bias in the decidua during early gestation in humans. Blood. 116, 2061-2069

Hudic, I. and Fatusic, Z., 2009. Progesterone - induced blocking factor (PIBF) and Th(1)/Th(2) cytokine in women with threatened spontaneous abortion. J Perinat Med. 37, 338-342

Jenmalm, M. C., Van Snick, J., Cormont, F.,Salman, B., 2001. Allergen-induced Th1 and Th2 cytokine secretion in relation to specific allergen sensitization and atopic symptoms in children. Clin Exp Allergy. 31, 1528-1535

Karmaus, W. and Eneli, I., 2003. Maternal atopy and the number of offspring: is there an association? Pediatr Allergy Immunol. 14, 470-474

Kwak-Kim, J. Y., Chung-Bang, H. S., Ng, S. C., Ntrivalas, E. I., Mangubat, C. P., Beaman, K. D., Beer, A. E.,Gilman-Sachs, A., 2003. Increased T helper 1 cytokine responses by circulating $T$ cells are present in women with recurrent pregnancy losses and in infertile women with multiple implantation failures after IVF. Hum Reprod. 18, 767-773

Lim, R. H., Kobzik, L.,Dahl, M., 2010. Risk for asthma in offspring of asthmatic mothers versus fathers: a meta-analysis. PLoS One. 5, e10134

Liu, C. A., Wang, C. L., Chuang, H., Ou, C. Y., Hsu, T. Y.,Yang, K. D., 2003. Prenatal prediction of infant atopy by maternal but not paternal total IgE levels. J Allergy Clin Immunol. 112, 899-904

Machura, E., Mazur, B., Rusek-Zychma, M.,Barc-Czarnecka, M., 2010. Cytokine production by peripheral blood CD4+ and CD8+ T cells in atopic childhood asthma. Clin Dev Immunol. 2010, 606139 
Makhseed, M., Raghupathy, R., Azizieh, F., Omu, A., Al-Shamali, E.,Ashkanani, L., 2001. Th1 and Th2 cytokine profiles in recurrent aborters with successful pregnancy and with subsequent abortions. Hum Reprod. 16, 2219-2226

Matthiesen, L., Ekerfelt, C., Berg, G.,Ernerudh, J., 1998. Increased numbers of circulating interferongamma- and interleukin-4-secreting cells during normal pregnancy. Am J Reprod Immunol. 39, 362-367

Milner, J. D., 2011. IL-17 producing cells in host defense and atopy. Curr Opin Immunol. 23, 784-788

Mjösberg, J., Berg, G., Jenmalm, M. C.,Ernerudh, J., 2010. FOXP3+ regulatory T cells and T helper 1, T helper 2, and T helper 17 cells in human early pregnancy decidua. Biol Reprod. 82, 698-705

Nakashima, A., Ito, M., Yoneda, S., Shiozaki, A., Hidaka, T.,Saito, S., 2010. Circulating and decidual Th17 cell levels in healthy pregnancy. Am J Reprod Immunol. 63, 104-109

Nilsson, L., Kjellman, N. I., Lofman, O.,Bjorksten, B., 1997. Parity among atopic and non-atopic mothers. Pediatr Allergy Immunol. 8, 134-136

Parronchi, P., De Carli, M., Manetti, R., Simonelli, C., Piccinni, M. P., Macchia, D., Maggi, E., Del Prete, G., Ricci, M.,Romagnani, S., 1992. Aberrant interleukin (IL)-4 and IL-5 production in vitro by CD4+ helper T cells from atopic subjects. Eur J Immunol. 22, 1615-1620

Parronchi, P., Macchia, D., Piccinni, M. P., Biswas, P., Simonelli, C., Maggi, E., Ricci, M., Ansari, A. A.,Romagnani, S., 1991. Allergen- and bacterial antigen-specific T-cell clones established from atopic donors show a different profile of cytokine production. Proc Natl Acad Sci U S A. 88, 4538-4542

Persson, M., Ekerfelt, C., Ernerudh, J., Matthiesen, L., Jenmalm, M., Jonsson, Y., Sandberg, M.,Berg, G., 2008. Increased circulating paternal antigen-specific IFN-gamma- and IL-4-secreting cells during pregnancy in allergic and non-allergic women. J Reprod Immunol. 79, 70-78

Peterson, R. A., 2012. Regulatory T-Cells: Diverse Phenotypes Integral to Immune Homeostasis and Suppression. Toxicol Pathol.

Prescott, S. L., Breckler, L. A., Witt, C. S., Smith, L., Dunstan, J. A.,Christiansen, F. T., 2009. Allergic women show reduced $T$ helper type 1 alloresponses to fetal human leucocyte antigen mismatch during pregnancy. Clin Exp Immunol. 159, 65-72

Raghupathy, R., Makhseed, M., Azizieh, F., Hassan, N., Al-Azemi, M.,Al-Shamali, E., 1999. Maternal Th1- and Th2-type reactivity to placental antigens in normal human pregnancy and unexplained recurrent spontaneous abortions. Cell Immunol. 196, 122-130

Raghupathy, R., Makhseed, M., Azizieh, F., Omu, A., Gupta, M.,Farhat, R., 2000. Cytokine production by maternal lymphocytes during normal human pregnancy and in unexplained recurrent spontaneous abortion. Hum Reprod. 15, 713-718

Sadeghnejad, A., Karmaus, W., Davis, S., Kurukulaaratchy, R. J., Matthews, S.,Arshad, S. H., 2004. Raised cord serum immunoglobulin $\mathrm{E}$ increases the risk of allergic sensitisation at ages 4 and 10 and asthma at age 10. Thorax. 59, 936-942

Sandberg, M., Frykman, A., Ernerudh, J., Berg, G., Matthiesen, L., Ekerfelt, C., Nilsson, L. J.,Jenmalm, M. C., 2009a. Cord blood cytokines and chemokines and development of allergic disease. Pediatr Allergy Immunol. 20, 519-527

Sandberg, M., Frykman, A., Jonsson, Y., Persson, M., Ernerudh, J., Berg, G., Matthiesen, L., Ekerfelt, C.,Jenmalm, M. C., 2009b. Total and allergen-specific IgE levels during and after pregnancy in relation to maternal allergy. J Reprod Immunol. 81, 82-88

Savilahti, E., Siltanen, M., Pekkanen, J.,Kajosaari, M., 2004. Mothers of very low birth weight infants have less atopy than mothers of full-term infants. Clin Exp Allergy. 34, 1851-1854

Seneviratne, S. L., Jones, L., Bailey, A. S., Black, A. P.,Ogg, G. S., 2006. Severe atopic dermatitis is associated with a reduced frequency of IL-10 producing allergen-specific CD4+ T cells. Clin Exp Dermatol. 31, 689-694 
Shimojo, N., Kohno, Y., Katsuki, T., Hoshioka, A., Honma, K., Saito, K.,Niimi, H., 1996. Diminished interferon-gamma (IFN-gamma) production by bacterial antigen-specific $\mathrm{T}$ cells in atopic patients. Clin Exp Immunol. 106, 62-66

Somoskovi, A., Bartfai, Z., Tamasi, L., Kocsis, J., Puho, E.,Czeizel, A. E., 2007. Population-based casecontrol study of allergic rhinitis during pregnancy for birth outcomes. Eur J Obstet Gynecol Reprod Biol. 131, 21-27

Sunyer, J., Anto, J. M., Plana, E., Janson, C., Jarvis, D., Kony, S., Omenaas, E. R., Svanes, C., Wjst, M.,Leynaert, B., 2005. Maternal atopy and changes in parity. Clin Exp Allergy. 35, 1028-1032

Tata, L. J., Hubbard, R. B., McKeever, T. M., Smith, C. J., Doyle, P., Smeeth, L., West, J.,Lewis, S. A., 2007. Fertility rates in women with asthma, eczema, and hay fever: a general populationbased cohort study. Am J Epidemiol. 165, 1023-1030

Wang, W. J., Hao, C. F., Qu, Q. L., Wang, X., Qiu, L. H.,Lin, Q. D., 2010a. The deregulation of regulatory $\mathrm{T}$ cells on interleukin-17-producing $\mathrm{T}$ helper cells in patients with unexplained early recurrent miscarriage. Hum Reprod. 25, 2591-2596

Wang, W. J., Hao, C. F., Yi, L., Yin, G. J., Bao, S. H., Qiu, L. H.,Lin, Q. D., 2010b. Increased prevalence of Thelper 17 (Th17) cells in peripheral blood and decidua in unexplained recurrent spontaneous abortion patients. J Reprod Immunol. 84, 164-170

Wegmann, T. G., Lin, H., Guilbert, L.,Mosmann, T. R., 1993. Bidirectional cytokine interactions in the maternal-fetal relationship: is successful pregnancy a TH2 phenomenon? Immunol Today. 14, 353-356

Westergaard, T., Begtrup, K., Rostgaard, K., Krause, T. G., Benn, C. S.,Melbye, M., 2003. Reproductive history and allergic rhinitis among 31145 Danish women. Clin Exp Allergy. 33, 301-305

Wu, M. Y., Chen, H. F., Chen, S. U., Chao, K. H., Yang, Y. S.,Ho, H. N., 2001. Increase in the production of interleukin-10 early after implantation is related to the success of pregnancy. Am J Reprod Immunol. 46, 386-392 


\section{Figure legends}

Figure 1. Flow chart of subjects included in this study. Among the 54 women who had a normal pregnancy and completed the sampling procedures, 12 fulfilled the criteria for allergy and 20 were non-allergic. Drop-outs $=$ women who chose not to participate in the study. Not strictly diagnosed = women with either a positive Phadiatop test and no symtoms, or a negative Phadiatop test and typical symtoms.

Figure 2. Levels of cytokines in cell supernatants in allergic and non-allergic pregnant women. a) Paternal antigen-induced IFN- $\gamma$ secretion; b) Pooled unrelated antigen-induced IFN- $\gamma$ secretion; c) Paternal antigen-induced IL-10 secretion; d) Pooled unrelated antigen -induced IL-10 secretion. Individual and median values are shown. $p$-values $<0.05$ from Mann Whitney $U$ test are indicated $(*)$.

Figure 3. Ratios of paternal antigen-induced cytokine production in allergic and non-allergic pregnant women. a) Paternal antigen-induced IFN- $/$ /IL-4 ratio; b) Paternal antigen-induced IFN- $\gamma /$ IL13 ratio; c) Paternal antigen-induced IL-10/IL-4 ratio; d) Paternal antigen-induced IL-10/IL-13 ratio. Individual and median values are shown. $p$-values $<0.05$ from Mann Whitney $\mathrm{U}$ test are indicated $(*)$.

Figure 4. Levels of cytokines in cell supernatants in non-allergic women with normal pregnancy. a) Pooled unrelated antigen-induced IFN- $\gamma$ secretion; b) Pooled unrelated antigen-induced IL-17 secretion; c) Pooled unrelated antigen-induced CCL17 secretion; d) Pooled unrelated antigen-induced CXCL10 secretion. Individual and median values are shown. $p$-values $<0.05$ from Wilcoxon signedrank test are indicated $(*)$. 
Cytokine levels in cell supernatants in allergic and non-allergic pregnant women

\begin{tabular}{|c|c|c|c|c|c|c|c|c|}
\hline & \multicolumn{2}{|c|}{ Gest. w. 10-12 } & \multicolumn{2}{|c|}{ Gest.w. 25} & \multicolumn{2}{|c|}{ Gest. w. 39} & \multicolumn{2}{|c|}{12 months $p p$} \\
\hline & Allergic & $\begin{array}{c}\text { Non- } \\
\text { allergic }\end{array}$ & Allergic & $\begin{array}{c}\text { Non- } \\
\text { allergic }\end{array}$ & Allergic & $\begin{array}{c}\text { Non- } \\
\text { allergic }\end{array}$ & Allergic & $\begin{array}{c}\text { Non- } \\
\text { allergic }\end{array}$ \\
\hline $\begin{array}{l}\text { IFN- } \gamma \\
\text { paternal } \\
\text { antigen }\end{array}$ & $\begin{array}{c}4.0 \\
(1.6-32.2)\end{array}$ & $\begin{array}{c}10.4 \\
(1.6-122.4)\end{array}$ & $\begin{array}{c}1.6 \\
(1.6-30.6)\end{array}$ & $\begin{array}{c}7.6 \\
(1.6-39.9)\end{array}$ & $\begin{array}{c}4.8 \\
(1.6-60.3)\end{array}$ & $\begin{array}{c}9.8 \\
(1.6-31.5)\end{array}$ & $\begin{array}{c}1.6 \\
(1.6-1.6)\end{array}$ & $\begin{array}{c}15.0 * \\
(1.6-49.8)\end{array}$ \\
\hline $\begin{array}{l}\text { IFN- } \gamma \\
\text { pooled } \\
\text { unrelated } \\
\text { antigen }\end{array}$ & $\begin{array}{c}4.7 \\
(1.6-32.8)\end{array}$ & $\begin{array}{c}5.0 \\
(1.6-82.1)\end{array}$ & $\begin{array}{c}2.5 \\
(1.6-16.7)\end{array}$ & $\begin{array}{c}10.9 * \\
(1.6-96.0)\end{array}$ & $\begin{array}{c}5.0 \\
(1.6-92.7)\end{array}$ & $\begin{array}{c}9.9 \\
(1.6-56.9)\end{array}$ & $\begin{array}{c}1.6 \\
(1.6-28.6)\end{array}$ & $\begin{array}{c}13.6 \\
(1.6-83.3)\end{array}$ \\
\hline $\begin{array}{l}\text { IL-4 } \\
\text { paternal } \\
\text { antigen } \\
\text { IL-4 }\end{array}$ & $\begin{array}{c}1.6 \\
(1.6-3.6)\end{array}$ & $\begin{array}{c}1.6 \\
(1.6-7.7)\end{array}$ & $\begin{array}{c}1.6 \\
(1.6-4.2)\end{array}$ & $\begin{array}{c}1.6 \\
(1.6-17.8)\end{array}$ & $\begin{array}{c}1.6 \\
(1.6-4.8)\end{array}$ & $\begin{array}{c}1.6 \\
(1.6-21.4)\end{array}$ & $\begin{array}{c}1.6 \\
(1.6-1.6)\end{array}$ & $\begin{array}{c}1.6 \\
(1.6-5.4)\end{array}$ \\
\hline $\begin{array}{l}\text { pooled } \\
\text { unrelated } \\
\text { antigen }\end{array}$ & $\begin{array}{c}1.6 \\
(1.6-3.6)\end{array}$ & $\begin{array}{c}1.6 \\
(1.6-33.3)\end{array}$ & $\begin{array}{c}1.6 \\
(1.6-1.6)\end{array}$ & $\begin{array}{c}1.6 \\
(1.6-8.3)\end{array}$ & $\begin{array}{c}1.6 \\
(1.6-4.2)\end{array}$ & $\begin{array}{c}1.6 \\
(1.6-12.5)\end{array}$ & $\begin{array}{c}1.6 \\
(1.6-1.6)\end{array}$ & $\begin{array}{c}1.6 \\
(1.6-8.3)\end{array}$ \\
\hline $\begin{array}{l}\text { IL-10 } \\
\text { paternal } \\
\text { antigen }\end{array}$ & $\begin{array}{c}3.82 \\
(1.6-30.9)\end{array}$ & $\begin{array}{c}19.0 \\
(1.6-522.8)\end{array}$ & $\begin{array}{c}8.8 \\
(1.6-71.3)\end{array}$ & $\begin{array}{c}24.6^{*} \\
(1.6-309.0)\end{array}$ & $\begin{array}{c}9.2 \\
(1.6-62.1)\end{array}$ & $\begin{array}{c}29.7 \\
(1.6-219.9)\end{array}$ & $\begin{array}{c}1.6 \\
(1.6-26.5)\end{array}$ & $\begin{array}{c}8.7 \\
(1.6-295.5)\end{array}$ \\
\hline $\begin{array}{l}\text { IL-10 } \\
\text { pooled } \\
\text { unrelated } \\
\text { antigen }\end{array}$ & $\begin{array}{c}3.5 \\
(1.6-35.9)\end{array}$ & $\begin{array}{c}16.5^{*} \\
(1.6-499.5)\end{array}$ & $\begin{array}{c}7.0 \\
(1.6-24.4)\end{array}$ & $\begin{array}{c}26.7^{*} \\
(1.6-260.4)\end{array}$ & $\begin{array}{c}15.5 \\
(1.6-362.5)\end{array}$ & $\begin{array}{c}36.1 \\
(1.6-94.8)\end{array}$ & $\begin{array}{c}1.6 \\
(1.6-35.3)\end{array}$ & $\begin{array}{c}15.4 \\
(1.6-201.3)\end{array}$ \\
\hline $\begin{array}{l}\text { IL-13 } \\
\text { paternal } \\
\text { antigen }\end{array}$ & $\begin{array}{c}2.4 \\
(1.0-5.4)\end{array}$ & $\begin{array}{c}3.7 \\
(1.0-39.1)\end{array}$ & $\begin{array}{c}1.0 \\
(1.0-19.5)\end{array}$ & $\begin{array}{c}2.9 \\
(1.0-54.6)\end{array}$ & $\begin{array}{c}2.0 \\
(1.0-14.1)\end{array}$ & $\begin{array}{c}1.0 \\
(1.0-30.8)\end{array}$ & $\begin{array}{c}1.0 \\
(1.0-2.8)\end{array}$ & $\begin{array}{c}1.0 \\
(1.0-62.4)\end{array}$ \\
\hline $\begin{array}{l}\text { IL-13 } \\
\text { pooled } \\
\text { unrelated } \\
\text { antigen }\end{array}$ & $\begin{array}{c}2.9 \\
(1.0-12.1)\end{array}$ & $\begin{array}{c}3.0 \\
(1.0-108.1)\end{array}$ & $\begin{array}{c}1.0 \\
(1.0-9.5)\end{array}$ & $\begin{array}{c}6.1 \\
(1.0-39.1)\end{array}$ & $\begin{array}{c}1.3 \\
(1.0-10.8)\end{array}$ & $\begin{array}{c}1.0 \\
(1.0-27.2)\end{array}$ & $\begin{array}{c}1.0 \\
(1.0-6.2)\end{array}$ & $\begin{array}{c}3.7^{*} \\
(1.0-93.8)\end{array}$ \\
\hline $\begin{array}{l}\text { IL-17 } \\
\text { paternal } \\
\text { antigen } \\
\text { IL-17 }\end{array}$ & $\begin{array}{c}0.3 \\
(0.3-6.4)\end{array}$ & $\begin{array}{c}1.6 \\
(0.3-15.7)\end{array}$ & $\begin{array}{c}0.3 \\
(0.3-20.5)\end{array}$ & $\begin{array}{c}2.7 \\
(0.3-19.4)\end{array}$ & $\begin{array}{c}0.3 \\
(0.3-3.7)\end{array}$ & $\begin{array}{c}1.4 \\
(0.3-45.4)\end{array}$ & $\begin{array}{c}0.3 \\
(0.3-2.1)\end{array}$ & $\begin{array}{c}0.3 \\
(0.3-7.0)\end{array}$ \\
\hline $\begin{array}{l}\text { pooled } \\
\text { unrelated } \\
\text { antigen }\end{array}$ & $\begin{array}{c}0.3 \\
(0.3-3.1)\end{array}$ & $\begin{array}{c}2.0 \\
(0.3-10.3)\end{array}$ & $\begin{array}{c}0.5 \\
(0.3-5.8)\end{array}$ & $\begin{array}{c}1.6 \\
(0.3-30.8)\end{array}$ & $\begin{array}{c}0.3 \\
(0.3-4.8)\end{array}$ & $\begin{array}{c}1.5 \\
(0.3-12.7)\end{array}$ & $\begin{array}{c}0.3 \\
(0.3-3.1)\end{array}$ & $\begin{array}{c}1.3 \\
(0.3-12.6)\end{array}$ \\
\hline $\begin{array}{l}\text { CXCL10 } \\
\text { paternal } \\
\text { antigen }\end{array}$ & $\begin{array}{c}1336.1 \\
(2.8- \\
6391.0)\end{array}$ & $\begin{array}{c}1083.8 \\
(2.8- \\
2667.0)\end{array}$ & $\begin{array}{c}1046.6 \\
(2.8- \\
6531.4)\end{array}$ & $\begin{array}{c}714.0 \\
(2.8- \\
3535.2)\end{array}$ & $\begin{array}{c}1578.4 \\
(2.8- \\
4342.9)\end{array}$ & $\begin{array}{c}1661.7 \\
(2.8- \\
5174.7)\end{array}$ & $\begin{array}{c}2.75 \\
(2.8-319.3)\end{array}$ & $\begin{array}{c}393.9^{*} \\
(2.8- \\
2667.0)\end{array}$ \\
\hline $\begin{array}{l}\text { CXCL10 } \\
\text { pooled } \\
\text { unrelated } \\
\text { antigen }\end{array}$ & $\begin{array}{c}880.6 \\
(2.8- \\
3899.3)\end{array}$ & $\begin{array}{c}936.1 \\
(2.8- \\
2667.0)\end{array}$ & $\begin{array}{c}546.8 \\
(2.8- \\
3604.2)\end{array}$ & $\begin{array}{c}1613.7 \\
(2.8- \\
5295.6)\end{array}$ & $\begin{array}{c}309.4 \\
(2.8- \\
4262.8)\end{array}$ & $\begin{array}{c}700.0 \\
(2.8- \\
5523.4)\end{array}$ & $\begin{array}{c}59.3 \\
(2.8- \\
2667.0)\end{array}$ & $\begin{array}{c}1194.6 \\
(2.8- \\
2667.0)\end{array}$ \\
\hline $\begin{array}{l}\text { CCL17 } \\
\text { paternal } \\
\text { antigen }\end{array}$ & $\begin{array}{c}49.2 \\
(1.0-193.0)\end{array}$ & $\begin{array}{c}37.5 \\
(1.0-206.1)\end{array}$ & $\begin{array}{c}25.6 \\
(1.0-267.0)\end{array}$ & $\begin{array}{c}66.2 \\
(1.0-228.4)\end{array}$ & $\begin{array}{c}48.1 \\
(1.0-180.8)\end{array}$ & $\begin{array}{c}27.9 \\
(1.0-213.4)\end{array}$ & $\begin{array}{c}1.0 \\
(1.0-26.7)\end{array}$ & $\begin{array}{c}26.0 \\
(1.0-341.3)\end{array}$ \\
\hline $\begin{array}{l}\text { CCL17 } \\
\text { pooled } \\
\text { unrelated } \\
\text { antigen }\end{array}$ & $\begin{array}{c}18.5 \\
(1.0-312.2)\end{array}$ & $\begin{array}{c}50.0 \\
(1.0-296.8)\end{array}$ & $\begin{array}{c}18.9 \\
(1.0-108.2)\end{array}$ & $\begin{array}{c}59.6 \\
(1.0-421.2)\end{array}$ & $\begin{array}{c}1.0 \\
(1.0-150.4)\end{array}$ & $\begin{array}{c}28.5 \\
(1.0-207.1)\end{array}$ & $\begin{array}{c}1.0 \\
(1.0-160.8)\end{array}$ & $\begin{array}{c}31.5 \\
(1.0-207.1)\end{array}$ \\
\hline
\end{tabular}


Note: Values are given in $\mathrm{pg} / \mathrm{mL}$ as median and (range)

* $p<0.05$ from Mann Whitney $U$ test 


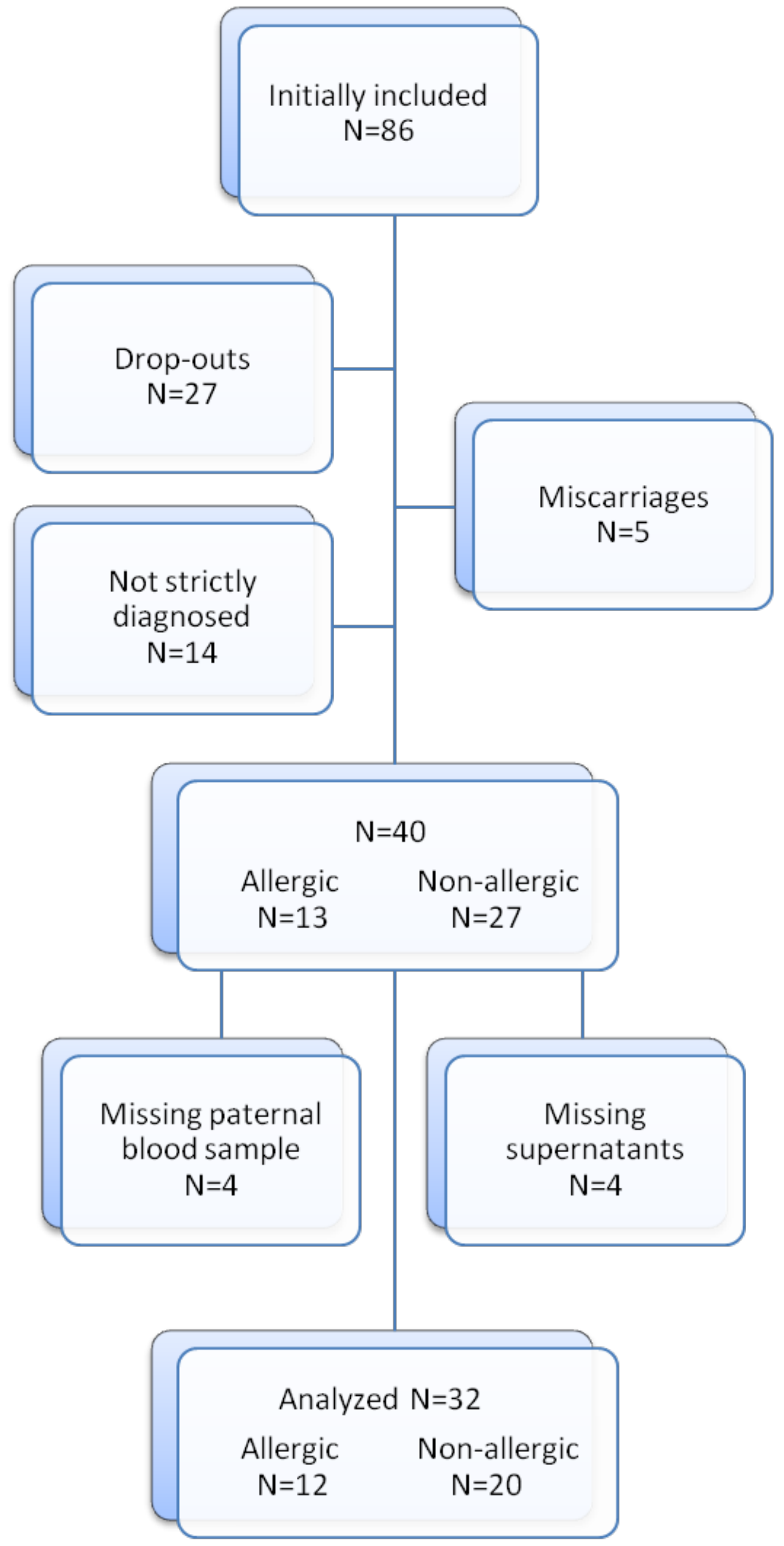



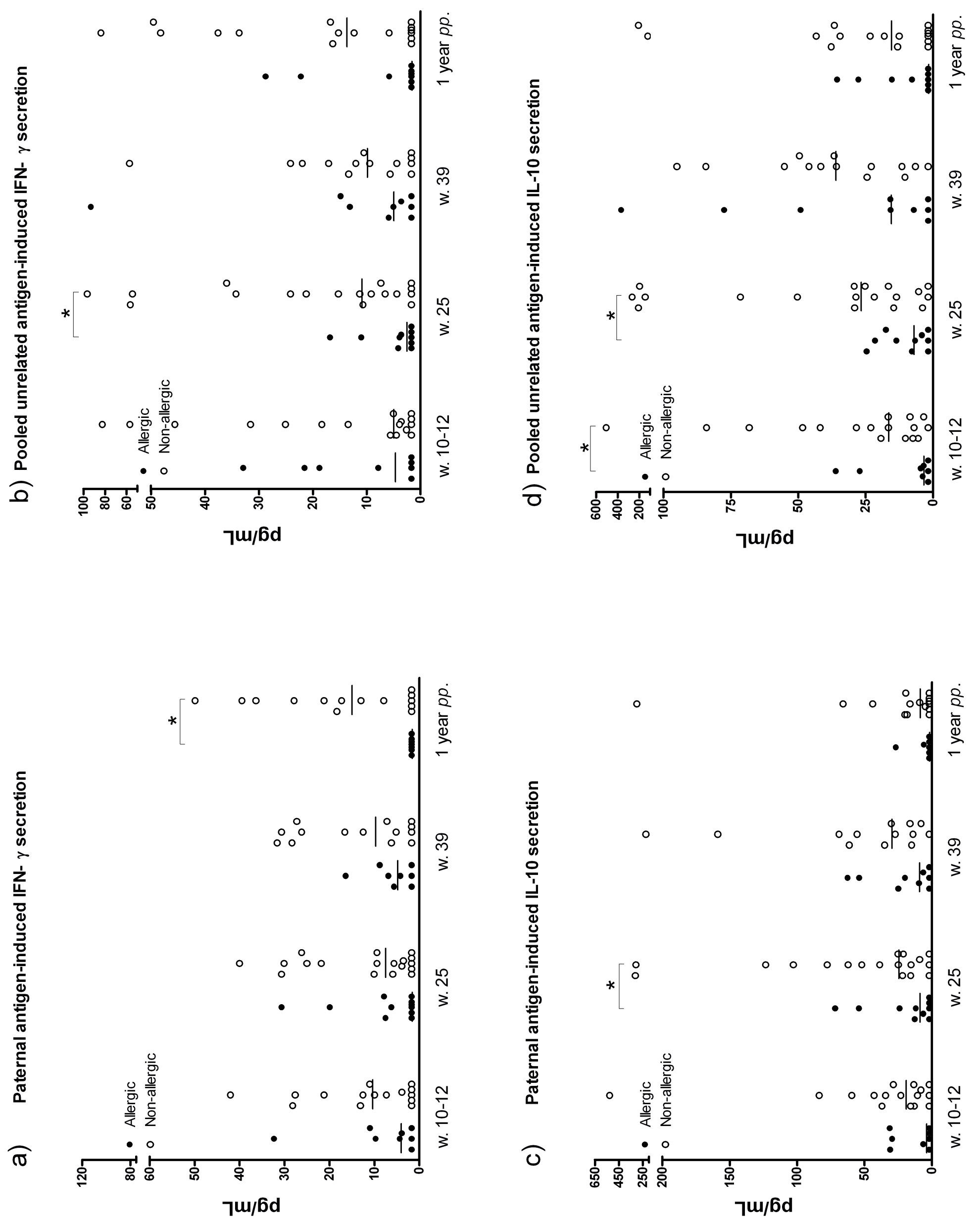

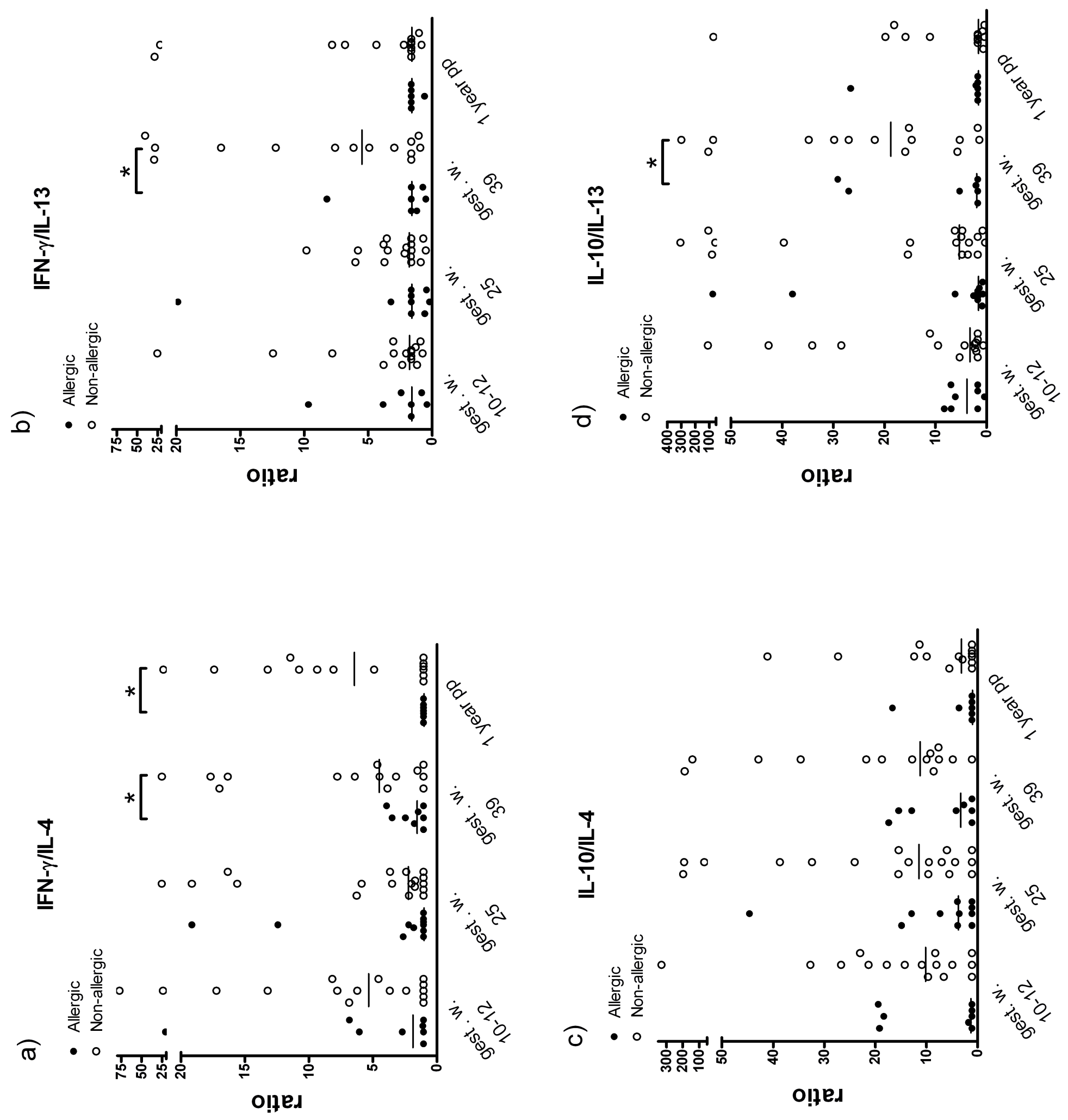


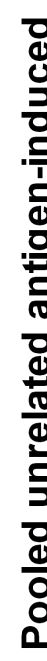
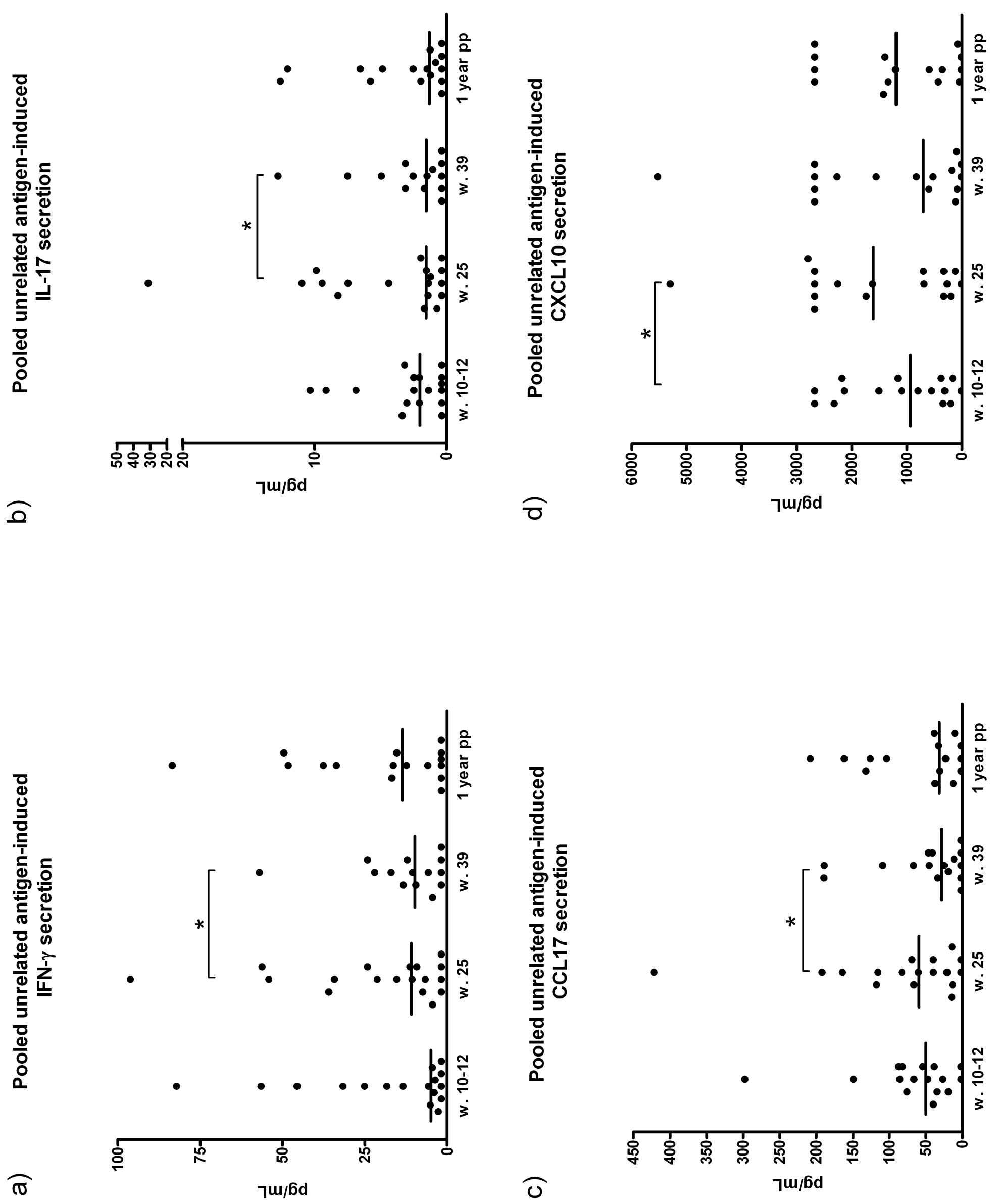